\title{
Bryophyte and pteridophyte spores and other palynomorphs in quaternary marine sediments from Campos Basin, southeastern Brazil: Core BU-91-GL-05'
} Aline Gonçalves de Freitas ${ }^{2}$, Marcelo de Araujo Carvalho ${ }^{3}$, Mauro Bevilacqua de Toledo ${ }^{4}$,
Claudia Barbieri Ferreira Mendonça ${ }^{5}$ and Vania Gonçalves-Esteves ${ }^{5^{*}}$

Received: September 3, 2014 Accepted: October 30, 2014

\begin{abstract}
This paper presents morphological descriptions and ecological data of cryptogam spores and other non-pollen palynomorphs from Quaternary sediments of Campos Basin, Rio de Janeiro, SE Brazil. The ages were derived from biostratigraphy of planktonic foraminifers and two radiocarbon dates, and suggest that sediment deposition started in the last 140,000 years BP. Thirty different types of palynomorphs were identified, described, and photographed: two bryophyte spores (sensu lato); 21 pteridophyte spores; four freshwater microalgae; onePseudoschizaea; and two microfungi. Some of the identified spores (Sphagnum, Blechnum, Cyatheaceae, Dennstaedtiaceae, Lycopodiella, Microgramma, Polypodium, Acrostichum, Pityrogramma, and Lygodium) are related to the modern flora found on the northern coast of Rio de Janeiro State, at the Restinga of Jurubatiba, from vegetation types such as shrub swamp/ coastal swamp formation, seasonally flooded forest, Clusia and Ericaceae woods, and disturbed vegetation. The freshwater microalgae and the microfungi are also presently recorded from the coastal lagoons of this region. The high spore concentration in slope sediments reflects the intense terrigenous influx, caused by a relative low sealevel during glacial stages. Palynological analysis suggests the presence of taxa from flooded forests and humid areas in the coastal plain during glacial and interglacial stages of the Late Pleistocene.
\end{abstract}

Keywords: Campos Basin; Late Pleistocene; non-pollen palynomorphs; paleoecology; spores

\section{Introduction}

As pollen and spore morphotypes are very similar to those produced by modern living plants, allowing precise taxonomic identifications at family and genera levels, and as they can indicate ecological processes that took place over timescales on the order of millennia, they are widely used in paleoenvironmental reconstructions on both local and regional geographical scales, together with other types of palynomorphs (Salgado-Labouriau 1994).

Even though palynological records from southern (Neves \& Lorscheitter 1996; Behling 2002; Neves \& Bauermann 2003; 2004; Medeanic 2006; Medeanic et al. 2006; Scherer \& Lorscheitter 2008; Cancelli et al. 2012) and southeastern Brazil (Freitas 2005; 2011; Luz et al. 2006; 2011; Toledo et al. 2009; Freitas \& Carvalho 2011; 2012) are far from complete, they provide a general picture that allows a better understanding of past vegetation and climate dynamics. They may also be used as a paleoenvironmental tool, especially for marine deposits (Lorscheitter \& Romero 1985; Behling et al. 2002; Freitas 2005; Freitas et al. 2007; 2013).

The deposition of spores and pollen grains in quaternary marine sediments of Campos Basin is mainly a function of riverine transport, which is strongly influenced by changes in the relative sea level during glacial-interglacial cycles during Pleistocene (Behling et al. 2002). These authors reported high percentage values of spores from tree ferns (e.g. Cyathea and Dicksonia), probably transported by the Paraíba do Sul river.

The evolution of the southeastern Brazilian coast was strongly affected by relative sea level changes that took place during Late Pleistocene, as the coastal plain was formed during two different stages of high sea level: in the previous interglacial (approximately 123,000 years BP) and most

\footnotetext{
${ }^{1}$ Based on the Master's dissertation of the first author

${ }^{2}$ Departamento de Biología Vegetal (Botánica), Facultad de Biología, Universidad de Murcia, 30100 Espinardo, Murcia, Spain

${ }^{3}$ Laboratório de Paleoecologia Vegetal, Departamento de Geologia e Paleontologia, Museu Nacional, Universidade Federal do Rio de Janeiro, 20940-040, Rio de Janeiro, RJ, Brazil

${ }^{4}$ Laboratório de Geologia Marinha, Universidade Federal Fluminense, 24220-008, Niterói, RJ, Brazil

${ }^{5}$ Laboratório de Palinologia, Departamento de Botânica, Museu Nacional, Universidade Federal do Rio de Janeiro, 20940-040, Rio de Janeiro, RJ, Brazil

* Corresponding author: esteves.vr@gmail.com
} 
recently (7000-5100 years BP) in the current interglacial (Martin et al. 1996). In the last glacial maximum (LGM), approximately 20,000-18,000 years BP, the relative sea level was 120 meters below the modern level (Viana et al. 1998) and rose rapidly until 7000-5000 years BP (Viana \& Faugères 1998). During low sea level stages, the rivers cut through the continental shelf and may have reached the upper continental slope, where paleochannels may be found today. The organic matter originated on the continent was probably transported through these channels and deposited straight onto the continental slope (Viana et al. 1998). Vicalvi (1997) built a biochronostratigraphic framework for Campos Basin on the basis of planktonic foraminifers, following Ericsson \& Wöllin (1968). As the BU-91-GL-05 core belongs to this framework, its chronology mainly derives from its biostratigraphy, which allows dating of sediment layers older than radiocarbon's oldest limit.

Two main groups of vascular plants compose the pteridophytes (ferns, horsetails, club mosses, and others): lycophytes and monilophytes (Juddet al. 2002). Smith et al. (2006) proposed a division of monilophytes into four classes: Psilotopsida, Equisetopsida, Marattiopsida, and Polypodiopsida. The largest concentration of pteridophyte species is found in the Mata Atlântica biome (834 species), followed by the Amazon region (428 species) and the Cerrado (245 species), with the highest species diversity found in the southeast and south Brazilian regions (Prado \& Sylvestre 2010).

This study presents morphological descriptions of bryophyte (sensu lato) and pteridophyte spores, freshwater algae, and microfungi found in Quaternary sediments from
Campos Basin, which is located to the northeast off the Rio de Janeiro coast. Throughout the analyzed core (Fig. 1) the relationship between the identified spores (fossil) and the modern flora of pteridophytes found in the vegetation formations on the continent is clear (Freitas 2005; Freitas et al. 2013). Therefore, these results along with the pollen data constitute an inventory of the Quaternary flora of SE Brazil, and may be a useful tool for other paleoclimate and paleoenvironmental reconstructions conducted in the SE region of Brazil.

\section{Hydrodynamics and depositional aspects of palynomorphs}

Hydrodynamical and meteorological aspects (Tyson 1995) control pollen and spore dispersal. Allochthonous palynomorphs are transported to the water after being released from the originating plant. At this dispersal stage, palynomorphs can spread out over large areas, and may be found very far from the source. The general rule of thumb is that the further the distance from the source plant, fewer palynomorphs are to be found in the sediments, and the opposite is also true, as most of the pollen and spores produced fall close to the plant that produced them. The floating time of palynomorphs on water mainly depends on the specific gravity of each palynomorph, palynomorph shape, and protoplasm decay rates. As palynomorph size is similar to that of silt and clay particles, when river transported, palynomorphs can overcome the barrier of waves and be deposited near the edge of the continental shelf and slope (Tyson 1995). On the continental slope thick layers of sediment can be carried to abyssal depths, mainly by turbidity currents through sub-

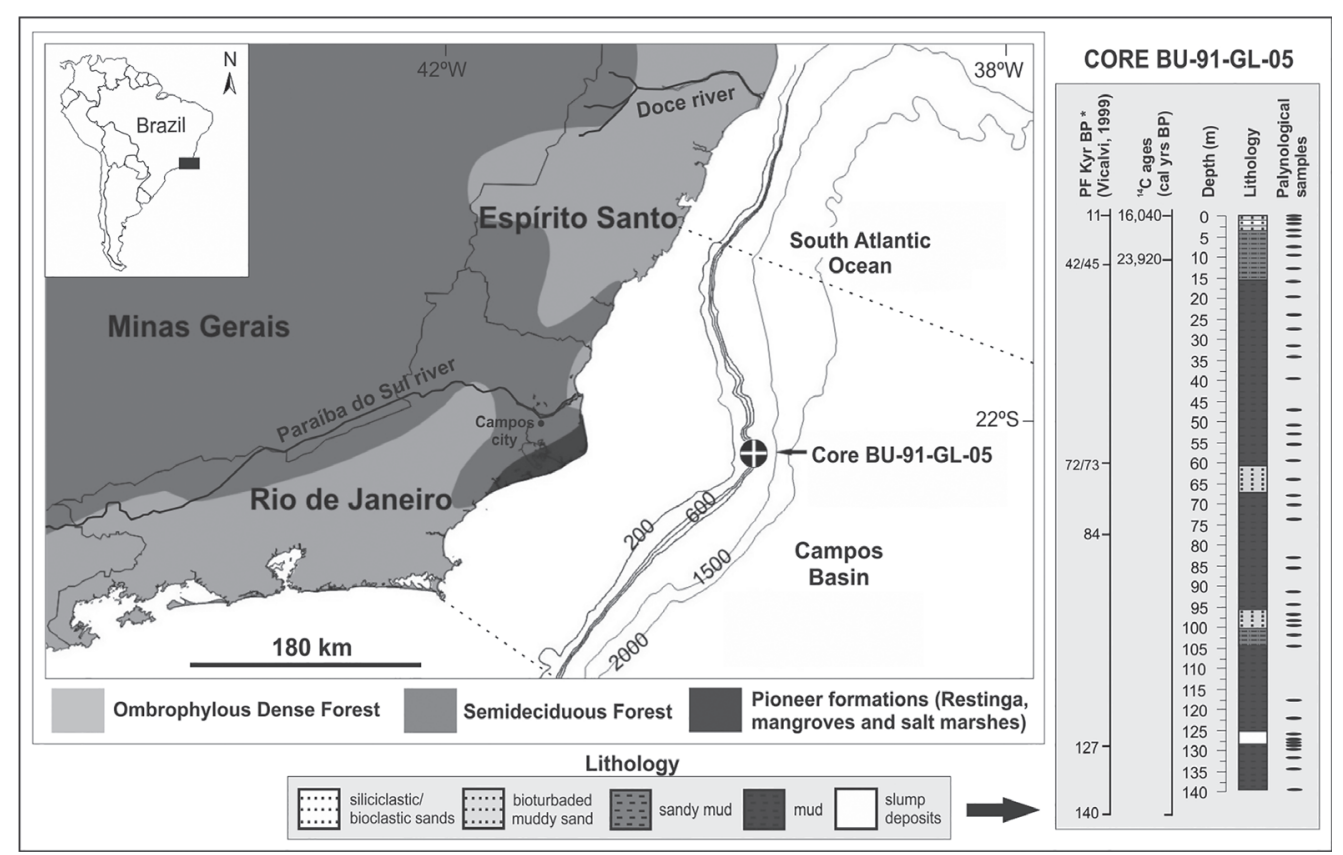

Figure 1. Location map of marine core BU-91-GL-05, Albacora Slope, Campos Basin, State of Rio de Janeiro, Brazil, and the current regional vegetation. ${ }^{\star}$ Ages estimated by planktonic foraminífera biozones. 
marine canions. The deposition patterns of palynomorphs in marine sediments are mainly a function of drainage basin characteristics, such as basin dimensons, and river discharge, among others (Mudie 1982), and as you go further offshore, the abundance of palynomorphs markedly decreases. In large river systems, such as the Amazon, Mississippi, Nile, and Orinoco rivers, the transport is much more efficient, and sediments and palynomorphs accumulate further from shore and faster than in other regions.

Gregory \& Hart (1992) promote the use of the pollen grain/spore ratio to infer relative sea level, because at low sea level, there is an increase of spore abundance, whereas pollen grains accumulate increasingly during conditions of high sea levels.

\section{Study area}

Campos Basin is located on the southeastern coast of Brazil, $21^{\circ}-23^{\circ} \mathrm{S}$, between Vitória High and Cabo Frio High (Fig. 1). The coastal plain of northern Rio de Janeiro is wide $\left(21^{\circ} 30^{\prime}-22^{\circ} 15^{\prime} \mathrm{S}\right)$, and because it includes the Paraiba do Sul River estuary, it is affected by both the river and the sea (Radambrasil 1983). As the Paraiba do Sul River is $1145 \mathrm{~km}$ long, and its drainage basin is $55,400 \mathrm{~km}^{2}$ (Molisani et al. 1999), including the mountain ridges of Serra do Mar and Serra da Mantiqueira (Behling et al. 2002), it constitutes a major terrigenous input of sediments (including continental palynomorphs) to the continental slope.

Climate is warm $\left(23^{\circ} \mathrm{C}\right)$ and humid, with wet summers and dry winters. The mean annual precipitation varies between 650 and $1000 \mathrm{~mm}$, and the dry season lasts 3-4 months (Nimer 1979).

The modern vegetation of the region is a mosaic of rain forest (Floresta Ombrófila Densa), seasonally dry forest (Floresta Estacional Semidecidual), coastal woodland and mangroves (pioneer formations), and cultivated areas (Radambrasil 1983). Phytosociological studies conducted in the region (Assumpção \& Nascimento 2000; Silva \& Nascimento 2001; Moreno et al. 2003; Pimentel et al. 2007) identified deciduous forests on top of Tertiary coastal plateaus, and a xerophytic type of vegetation (restinga) near the shore. The restinga vegetation is strongly influenced by the sea, and presents several grades of physiognomy (i.e., from herbaceous to shrubby woodlands). Along the entire coast, mangroves are also easily found (IBGE 1992) (Fig. 1). In addition, the Jurubatiba Coastal Woodlands National Park, a very important conservation area located in this region, harbors many restinga ecosystems (Costa \& Dias 2001; Pereira et al. 2004; Montezuma \& Araujo 2007).

The marine currents carry sediments, including organic matter and palynomorphs, over the continental shelf (where submarine canyons are abundant) from the continent to the continental slope. Estimated sedimentation rates are higher for the Pleistocene $(40-140 \mathrm{~cm} / 1000$ years) than during the Holocene ( $12.7 \mathrm{~cm} / 1000$ years) (Vicalvi 1997). The amount of airborne palynomorphs deposited in these marine sediments is supposedly negligible because the prevailing wind direction is from the sea to the land (Nimer 1979), although dry winds occasionally blow from the west and northwest (Ybert 1980).

\section{Material and methods}

The sediment core BU-91-GL-05 (22 $08^{\prime} 12^{\prime \prime}$ 's; 3954'53" $\mathrm{W})$ is $149.5 \mathrm{~m}$ long and it was raised from a $630 \mathrm{~m}$ water depth from the Albacora Slope, northern Campos Basin (Fig. 1). The core is composed mainly of organic mud alternated with sand layers (63-65m and $97-100 \mathrm{~m}$ depth) and a slump deposit (126.7-127.85m depth) (Caddah et al. 1998) (Fig. 1). The age model is based on biostratigraphy of planktonic foraminifers (Vicalvi 1997) and radiocarbon ages from 1.3-1.5m and 10.2-10.4m depths (Tab. 1). The radiocarbon dates (AMS) were obtained at the Beta Analytic Inc. (USA) and calibrated using the latest IntCal09 curve (Ramsey et al. 2009) on Calib 6.1.1 software (Stuiver \& Reimer 1993).

Forty-three samples (10-20g of sediment each) were used for palynological analysis. The chemical attack avoided organic matter oxidation and followed Tyson (1995) and Mendonça Filho et al. (2002), using hydrochloric and fluoric acids to dissolve carbonates and silicates, and heavy liquid separation with zinc chloride $(D=2.0)$ to concentrate the organic residue. The palynological slides are stored at the Laboratório de Paleoecologia Vegetal, in the Departamento de Geologia e Paleontologia of Museu Nacional, Universidade Federal do Rio de Janeiro. For each sample, were counted between 200-300 palynomorphs, with the exception of just a few samples where concentration was to low $(0.3$ m, $1.3 \mathrm{~m}, 64.62 \mathrm{~m}, 70.45 \mathrm{~m}, 86.17 \mathrm{~m}, 99.75 \mathrm{~m}$ e $128.5 \mathrm{~m}$ ), which coincided with sand layers in the core (Freitas 2005).

The taxonomic identification was based on morphological features such as polarity, size, amb (shape and symmetry), and exospore ornamentation. Regarding the scars or laesurae, the spores may be called alete (no laesura), monolete (a single laesura), or trilete (three laesurae or a triradiate laesura). In the photographs, the laesurae will always be in proximal view, facing the center of the tetrad (Traverse 1988). The descriptive terminology follows the International Code of Botanical Nomenclature (ICBN), glossaries of pollen and spore terminology (Punt et al. 2007; Ybert et al. 2012), and further publications from Erdtman

Table 1. ${ }^{14} \mathrm{C}$ dating of the BU-91-GL-05 core, Albacora Slope. Ages were calibrated based on Stuiver \& Reimer (1993) and Ramsey et al. (2009), with the IntCal09 calibration curve.

\begin{tabular}{ccccc}
\hline Lab code & Depth $(\mathbf{m})$ & ${ }^{14}$ C yrs BP & $\begin{array}{c}\text { Calibrated age } \\
(\text { cal yr BP) }\end{array}$ & $\begin{array}{c}\boldsymbol{\delta}^{13} \mathbf{C} \\
(\%)\end{array}$ \\
\hline Beta-270653 & $1.3-1.5$ & $13,220 \pm 70$ & $(16,040) 16,670-15,400$ & $-25,4$ \\
Beta-270652 & $10.2-10.4$ & $20,020 \pm 100$ & $(23,920) 24,310-23,530$ & $-22,7$ \\
\hline
\end{tabular}


(1969), Roubik \& Moreno (1991); Leal \& Lorscheitter (2006); Leonhardt \& Lorscheitter (2007) and Freitas et al. (2007). Quantitative (percentage) of pteridophyte spores identified is exposed in Fig. 2.

Studies of fossil microfungi usually follow Saccardo (1931), which is based on number of cell and septa organization. However, in more recent taxonomic studies (Kalgutkar \& Jansonius 2000), it has been suggested a few modifications to this system, due to the morphological complexity that has been found in both fossil and modern fungi, with a special regard to presence/absence of apertures (pores or colpi). Therefore, the identification and description of non-palynological palynomorphs (e.g. freshwater algae, microfungi, and pseudoschizaea) were carried out following Christopher (1976), Geel \& Hammen (1978); Kalgutkar \& Jansonius (2000); Freitas et al. (2007); Freitas \& Carvalho (2011). All the photographs (Figs. 3-5) were taken on a transmitted light Zeiss microscope under 400x and 1000x magnification, using Axiovision software 6.0 (Carl Zeiss, Oberkochen, Germany).

\section{Results and discussion}

\section{Palynological Analysis}

In the studied samples, Pteridophyte spores make up to $83 \%$ of land palynomorphs (Fig. 2). Thirty palynomorphs have been identified, described, and photographed. Two types of Bryophyte spores (sensu lato) have been identified: Sphagnum and Phaeoceros; 21 types of Pteridophyte spores, with 3 types being lycophytes (Lycopodium, Lycopodiella and Selaginella) and 18 pteridophytes (or monilophytes) (Marattiaceae, Anemia, Lygodium, Alsophila, Cyatheaceae,

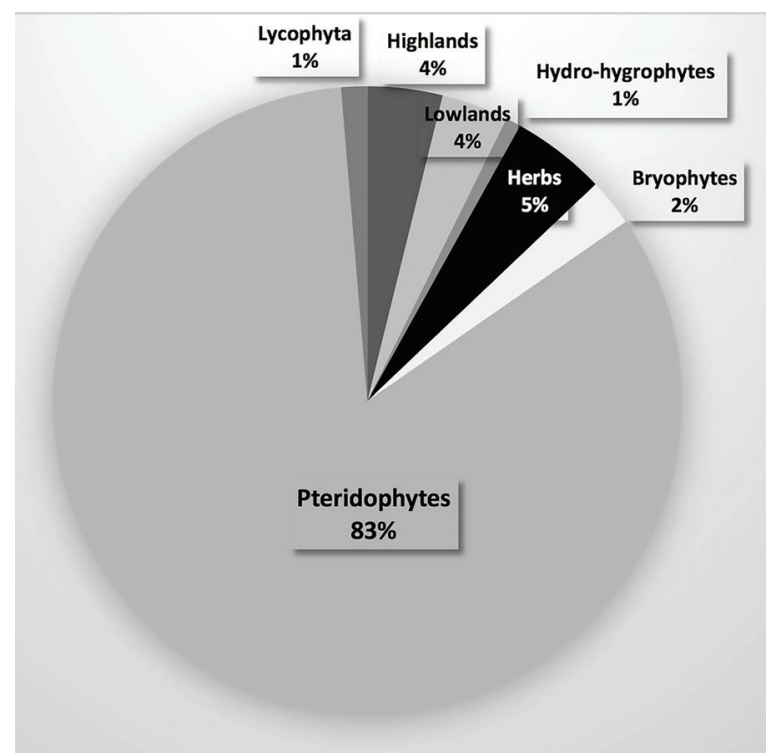

Figure 2. Percentage of terrestrial palynomorphs registered on core BU-91GL-05. The pollen sum included pollen and non-pollen palynomorphs.
Hemitelia, Lophosoria, Dennstaedtiaceae, Acrostichum, Adiantum, Cheilanthes, Pityrogramma, Pteris, Asplenium, Blechnum, Microgramma, Polypodium and Vittaria), four freshwater algae (Botryococcus, Debarya, Zygnema and Spirogyra), 1 incertae sedis (Pseudoschizaea), 1 fungal spore (Diporisporites) and 1 fungal fruiting body (Microthyrium) (Figs. 3-5).

\section{Morphological descriptions}

\section{Bryophytes (sensu lato)}

Division Bryophyta

Class Sphagnidae

Order Sphagnales

Family Sphagnaeceae

1. Sphagnum (Dill.) Hedwg Fig. 3A

Description: trilete spores, monads, medium size, radially symmetric, heteropolar, sub-triangular in polar view. Psilate exosporium, perine is absent. Equatorial axis: 45.8$49.4 \mu \mathrm{m}$. Ecological Data: peat bog moss usually found in waterlogged areas and in moist acidic soils of forests and restinga, swamps and wetlands, river and lake margins, and grasslands. Occurrence: peat bogs from intermediate valley of Paraiba do Sul River (São Paulo State). In peat bogs, moist soils, and quaternary coastal sediments from Rio Grande do Sul State (Neves \& Bauermann 2003; Medeanic 2006), Doce River delta (Espirito Santo State) (Ferrazo et al. 2008) and the herbaceous-swampy formation of the Jurubatiba Coastal Woodlands National Park (Rio de Janeiro State) (Santos et al. 2004) and south and southeastern presenteday bryoflora of Brazil (Tab. 2). Core Record: E.F. (England Finder) coordinates: O46/4, 1000x magnification, GL05/35 (123.05 m depth). References: Leal \&Lorscheitter (2006).

\section{Division Anthocerotophyta \\ Class Anthocerotopsida \\ Order Anthocerotales \\ Family Anthocerotaceae}

\section{Phaeoceros Prosk. Fig. 3B-C}

Description: trilete spores, monads, medium-large size, radially symmetric, heteropolar, circular to sub-triangular in polar view. Rugulate to reticulate-echinate exosporium. Equatorial axis: 46.6-53.3 $\mu \mathrm{m}$. Ecological data: moist soils and shaded areas with fully developed vegetation cover, such as river margins, agricultural fields, or associated with other bryophytes (Menendez 1962). Occurrence: peat bogs from intermediate valley of Paraiba do Sul River (São Paulo State). In peat bogs, moist soils, and Quaternary coastal sediments from Rio Grande do Sul State (Neves \& Bauermann 2003; Medeanic, 2006). Also found in Holocene sediments from Buenos Aires, Argentina (Prieto \& Quattrocchio 1993). Core Record: E.F. coordinates E41, 1000x magnification, GL05/38 (128.1 m depth). References: Leal \& Lorscheitter (2006). 
Table 2. Relationships between plant spores registered in this work and the present-day taxa occurrence in plant communities at "Jurubatiba Coastal Woodlands National Park" (Rio de Janeiro State). References: Santos \& Sylvestre (2001) and Santos et al. (2004).

\begin{tabular}{|c|c|c|c|c|c|}
\hline \multirow[b]{2}{*}{ Fosil plant spores } & \multicolumn{5}{|c|}{ Restinga vegetation } \\
\hline & $\begin{array}{l}\text { Post-beach dense } \\
\text { shrubby formation }\end{array}$ & $\begin{array}{l}\text { Open Clusia and } \\
\text { Ericaceae scrub } \\
\text { formations }\end{array}$ & $\begin{array}{l}\text { Herbaceous-swampy } \\
\text { formation }\end{array}$ & $\begin{array}{l}\text { Swamp forest } \\
\text { formation }\end{array}$ & Disturbed areas \\
\hline Sphagnaceae Sphagnum & - & - & $\mathrm{x}$ & - & - \\
\hline Lycopodiaceae Lycopodiella & - & - & $\mathrm{x}$ & - & - \\
\hline Lygodiaceae Lygodium & - & - & - & $\mathrm{x}$ & $\mathrm{x}$ \\
\hline Cyatheaceae & - & - & - & $\mathrm{x}$ & $\mathrm{x}$ \\
\hline Dennstaedtiaceae & - & - & $\mathrm{x}$ & $\mathrm{x}$ & $\mathrm{x}$ \\
\hline Pteridaceae Acrostichum & - & - & $\mathrm{x}$ & $\mathrm{x}$ & $\mathrm{x}$ \\
\hline Pteridaceae Pityrogramma & - & $\mathrm{x}$ & - & $\mathrm{x}$ & $\mathrm{x}$ \\
\hline Blechnaceae Blechnum & - & - & - & $\mathrm{x}$ & $\mathrm{x}$ \\
\hline Polypodiaceae Microgramma & $\mathrm{x}$ & $\mathrm{x}$ & - & $\mathrm{x}$ & - \\
\hline Polypodiaceae Polypodium & $\mathrm{x}$ & $\mathrm{x}$ & - & $\mathrm{x}$ & - \\
\hline
\end{tabular}

\section{Pteridophytes}

Division Lycopodiophyta

Class Lycopodiopsida

Order Lycopodiales

Family Lycopodiaceae

3. Lycopodium L. Fig. 3D

Description: trilete spores, monads, medium size, radially symmetric, heteropolar, sub-triangular in polar view. Reticulate exosporium. Equatorial axis: 39-42.8 $\mu \mathrm{m}$. Ecological Data: dry land or rupiculous herbaceous commonly found in the Atlantic rain forest associated to semi-open areas (Tryon \& Tryon 1982 apud Leonhardt \& Lorscheitter 2007). Occurrence: Itatiaia plateau (between Rio de Janeiro and Minas Gerais states) (Ramos \& Sylvestre 2010). Core Record: E.F. coordinates H39/2, 1000x magnification, GL05/17 (51.63 m depth). References: Medeanic (2006) and Leonhardt \& Lorscheitter (2007).

\section{Lycopodiella Holub Fig. 3E}

Description: trilete spores, monads, medium size, radially symmetric, heteropolar, sub-triangular in polar view. Reticulate exosporium with evenly distributed small pits, perine is absent. Equatorial axis: 45.2-47.3 $\mu \mathrm{m}$. Comments: resembles Lycopodiella aloperculoides (L.) Cranfill recorded by Scherer \& Lorscheitter (2008). Ecological Data: dry land herbaceous commonly found in the lowland Atlantic rain forest and restinga, it is a component of wetland herbaceous formation associated with Drosera intermedia, Lindsea stricta var. stricta and Sphagnum. Occurrence: Atlantic forest inselbergs from Rio de Janeiro State (Santos \& Sylvestre 2006) and south of Espírito Santo State (Aquije \& Santos 2007). In northern Rio de Janeiro, at the Jurubatiba Coastal Woodlands National Park (Santos \& Sylvestre 2001; Santos et al. 2004) (Tab. 2), Itatiaia Plateau (Rio de Janeiro and Minas Gerais states) (Ramos \& Sylvestre 2010), in Quaternary peat bogs in Araucaria forest (plateau), and in the coastal plain of Rio Grande do Sul State. Core Record: E.F. coordinates H39/2, 1000x magnification, GL05/17 (51.63 m depth). References: Medeanic (2006) and Leonhardt \& Lorscheitter (2007).

Order Selaginellales

Family Selaginellaceae

5. Selaginella P. Beauv. Fig. 3F

Description: trilete spores, monads, medium size, radially symmetric, heteropolar, circular to sub-triangular in polar view. Baculate exosporium, perine is absent. Equatorial axis: 34.5-37.2 $\mu \mathrm{m}$. Comments: it is considered on of the most diverse genus recorded in Brazil (Prado \& Sylvestre 2010). Ecological Data: moist environments (Lorscheitter et al. 1999 apud Cancelli et al. 2012). Occurrence: recorded in Atlantic forest inselbergs from Rio de Janeiro (Santos \& Sylvestre 2006) and Espírito Santo states (Aquije \& Santos, 2007). Also recorded in mesophillous woodlands at $1500 \mathrm{~m}$ a.s.l. (above sea level) in central Sierra Madre, Mexico (Gomez-Noguez et al. 2013), and in Holocene sediments from the coastal plain south of Santa Catarina State (Cancelli et al. 2012). Core Record: E.F. coordinates U53/2, 1000x magnification, GL05/08 (13.75 m depth). References: Roubik \& Moreno (1991).

\section{Division Pterydophyta \\ Class Marattiopsida \\ Order Marattiales \\ Family: Marattiaceae}

\section{Marattiaceae Fig. 3G}

Description: monolete spores, monads, medium size, bilaterally symmetric, heteropolar, with ellipsoidal shape. Echinated exosporium, with spines distributed throughout the surface, perine is absent. Longest Equatorial axis: $32.5-40$ $\mu \mathrm{m}$. Polar axis: 26.6-32.5 $\mu \mathrm{m}$. Comments: resambles Danaea spp. Ecological Data: recorded as herbaceous living within 
forest fragments at the Zona da Mata (Coastal Atlantic Forest) in Pernambuco State (Pereira et al. 2007). Occurrence: at Atlantic Rain Forest of southern Espírito Santo State (Aquije \& Santos 2007) and at the Ecological Reserve of Gurjaú, Cabo de Santo Agostinho County (Pernambuco State, NE Brazil), where it is considered to be a rare species (D. bipinnata) with a new record in Pernambuco State. Core Record: E.F. coordinates E41, 1000x magnification, GL05/38 (128.1 m depth). References: Roubik \& Moreno (1991).

Class Pteridopsida

Order Schizaeales

Family Anemiaceae

7. Anemia Sw. Fig. 3H-I

Description: trilete spores, monads, large size, radially symmetric, heteropolar, subtriangular. Striate exosporium (cicatricose) with bacula of varying length. Longest equatorial axis: $50-61.3 \mu \mathrm{m}$. Short equatorial axis: $43-53.3 \mu \mathrm{m}$. Comments: one of the most diverse genera recorded in Brazil (Prado \& Sylvestre 2010). Ecological Data: herbaceous species present in several habitats, such as shaded areas, hills, and roadsides (Lorscheitter et al. 1998 apud Macedo et al. 2009). Occurrence: recorded in Atlantic Rain Forest inselbergs of Rio de Janeiro (Santos \& Sylvestre 2006) and Espírito Santo states (Aquije \& Santos 2007). Also found in Holocene sediments of Buenos Aires, Argentina (Prieto \& Quattrocchio 1993). Core Record: E.F. coordinates H39/2, 1000x magnification, GL05/17 (51.63 m depth). References: Garcia (1997) and Macedo et al. (2009).

Family Lygodiaceae

8. Lygodium Sw. Fig. 3J

Description: trilete spores, monads, medium-large size, radially symmetric. Verrucate exosporium, perine is present. Longest axis: 65.7-70.6 $\mu \mathrm{m}$; short axis: 45.2-46.6 $\mu \mathrm{m}$. Ecological Data: herbaceous species present in humid tropical forests of South and Central America, Atlantic Rain Forest (lowlands and highlands), restinga and disturbed vegetation. Occurrence: Carapebus, northern Rio de Janeiro State, found in seasonally flooded forests (Santos \& Sylvestre 2001) (Tab. 2). Also recorded in peat bogs of intermediate valley of Paraiba do Sul River (Garcia 1997). Core Record: E.F. coordinates U53/2, 1000x magnification, GL05/08 (13.7 m depth). References: Roubik \& Moreno (1991).

Order Cyatheales

Family Cyatheaceae

9. Alsophila R. Br. Fig. 3K

Description:trilete spores, monads, medium size, radially symmetric, with triangular amb. Scabrate exosporium, and psilate perine. Axes: 36.6 x $38.8 \mu \mathrm{m}$. Comments: Cyathea is one of the most diverse genera recorded in Brazil (Prado \& Sylvestre 2010). Ecological Data: arborescent species present in primary and secondary forest formations in the south and southeast Brazil. Its caudex is used as microhabi- tat by other pteridophytes that are epyphytes (e.g. Asplenium, Blechnum, Microgramma, Polypodium and Vittaria) (Schmitt \& Windisch 2005). Occurrence: recorded in the hills with Atlantic Rain Forest of southern Espírito Santo State and SE Brazil (Aquije \& Santos 2007). Core Record: E.F. coordinates M54/3, 1000x magnification, GL05/34 (118.8 m depth). References: Garcia (1997).

\section{Cyatheaceae Sm. Fig. 3L-N}

Description:trilete spores, monads, medium size, radially symmetric. Verrucate to granulate exosporium, perine is sometimes present. Axes: $38.2-45.5 \times 33.6-43.3 \mu \mathrm{m}$. Ecological Data: arborescent ferns from tropical and sub-tropical regions, found in montane humid forests, riverine, rocky areas and restinga formations (Santos \& Sylvestre 2001; Tryon \& Tryon 1982 apud Scherer \& Lorscheitter 2008). Occurrence: it is found in hills with Atlantic Rain Forest from southern Espírito Santo State (Serra do Mar mountain range) (Graçanho et al. 1998 apud Aquije \& Santos 2007) and the swamp forest and disturbed areas of Jurubatiba Coastal Woodlands National Park (Rio de Janeiro State) (Tab. 2). Core Record: E.F. coordinates H41, 1000x magnification, GL05/14 (34.7 m depth) and E41, 1000x magnification, GL05/38 (128.1 m depth). References: Roubik \& Moreno (1991).

\section{Hemitelia R. Br. Fig. 4A}

Description: trilete spores, monads, medium size, radially symmetric. Psilate exosporium, with 3 perforations distributed in the equatorial zone. Axes: $37.5 \times 33.3 \mu \mathrm{m}$. Ecological Data: arborescent fern from temperate climate, mainly found in the lower portions of montains (Lorente 1986 apud Santos et al. 2005). Occurrence: Foz do Amazonas Basin (Carvalho 2003; Santos et al. 2005) and Orenoco River Delta, in Venezuela (Müller 1959). Core Record: E.F. coordinates E52, 1000x magnification, GL05/14 (98.7 m depth). References: Müller (1959) and Santos et al. (2005).

\section{Family Dicksoniaceae}

\section{Lophosoria C.Presl. Fig. 4B}

Description: trilete spores, monads, large size, radially symmetric, semi-circular shape. Granulate-tuberculate exosporium in proximal view and foveolate exosporium in distal view. Thin microreticulate perine. Axes: 58.4 x 61.5 $\mu \mathrm{m}$. Comments: resembles Lophosoria quadripinnata (J.F. Gmel.) C. Chr. var quadripinnata. Ecological Data: arborescent ferns $(2.5-5 \mathrm{~m})$ found within forest patches and on the borders as well, mainly in shaded areas (Palacios-Rios 1994; Coelho \& Esteves 2008b). Occurrence: In peat bogs from intermediate valley of Paraiba do Sul River (Garcia et al. 2004) and Atlatic Rain Forest of Parque Estadual Fontes, do Ipiranga, São Paulo State (Coelho \& Esteves 2008b). Also recorded in mesophilous woods at $1500 \mathrm{~m}$ a.s.l., at Sierra Madre Central, México (Gomez-Noguez et al. 2013). Core Record: E.F. coordinates H41, 1000x magnification, 

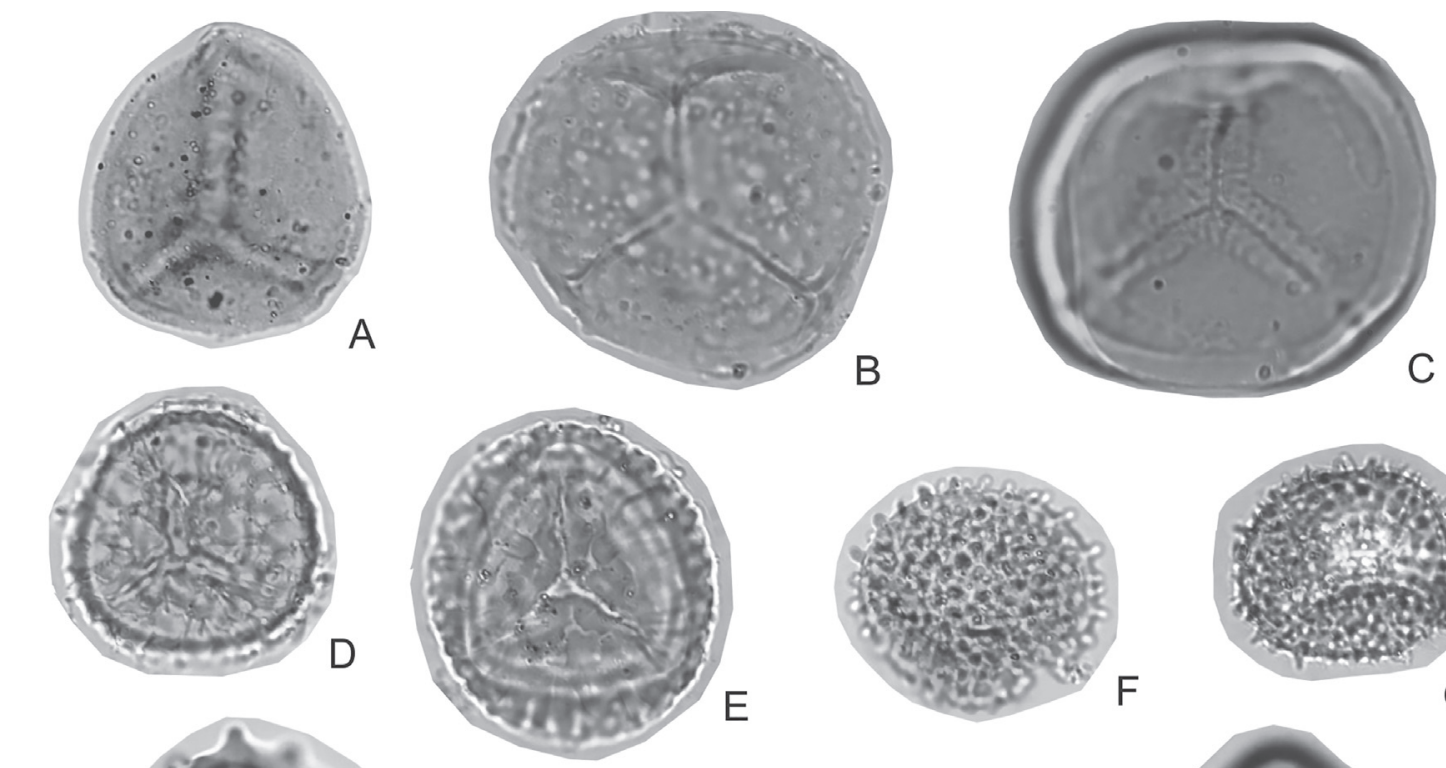

B
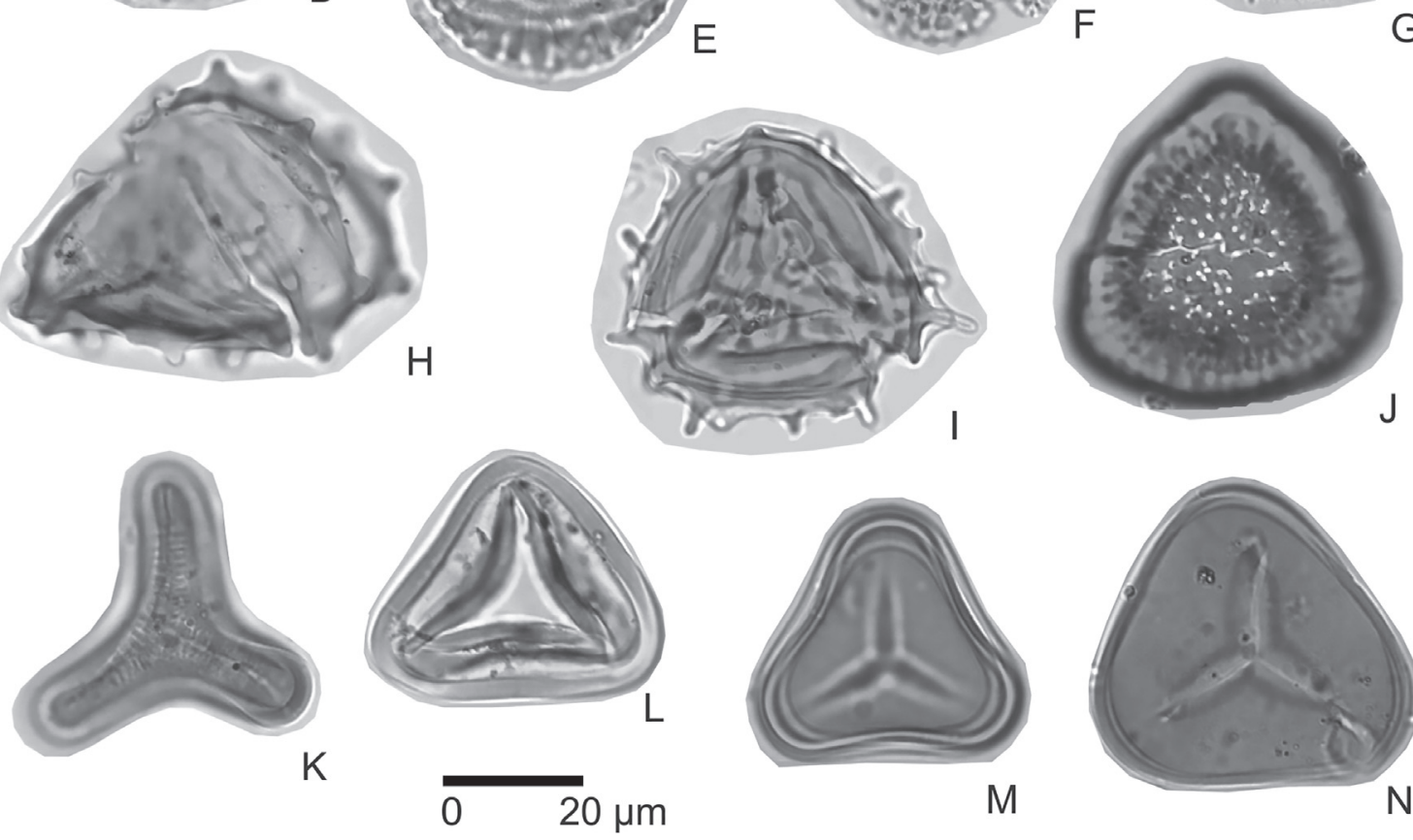

M

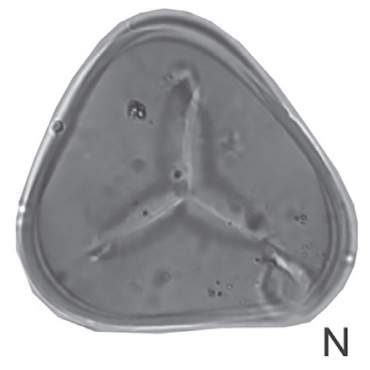

Figure 3. Photomicrographs of cryptogam spores registered in core BU-91-GL-05 (magnification, $\geq 400 \mathrm{x}$ and 1000x). Bryophyta (sensu lato): A. Sphagnum; B-C. Phaeoceros. Pteridophyta: Lycophyta: D. Lycopodium; E. Lycopodiella; F. Selaginella. Monilophyta: G. Marattiaceae; H-I. Anemia; J. Lygodium; K. Alsophila; L-N. Cyatheaceae. Scale: $20 \mu \mathrm{m}$.

GL05/14 (34.7 m depth). References: Coelho \& Esteves (2008b) and Gomez-Noguez et al. (2013).

Order Polypodiales

Family Dennstaedtiaceae

13. Dennstaedtiaceae Fig. 4C

Description: trilete spores, monads, medium-large size, radially symmetric. Verrucate exosporium. Axes: $47 \mathrm{x}$ $61.4 \mu \mathrm{m}$. Ecological Data: herbaceous species common in ombrophilous forest (Atlantic Rainforest) and restinga (Coastal Sand Plain Vegetation). Occurrence: lowland and highland Atlantic Rain Forest, and restinga. Recorded in the hills of Atlantic Forest from southern Espirito Santo State (Aquije \& Santos 2007). In Carapebus (northern
Rio de Janeiro State) is found Clusia and Ericaceae formations, in the edge of seasonally swamp forests of the Jurubatiba Coastal Woodlands National Park (Santos \& Sylvestre 2001) (Tab. 2), and also in the peat bogs of the intermediate valley of Paraíba do Sul River (Garcia et al. 2004). Core Record: E.F. coordinates U53/2, 1000x magnification, GL05/08 (13.75 m depth). References: Roubik \& Moreno (1991).

Family Pteridaceae

14. Acrostichum L. Fig. 4D

Description: trilete spores, monads, medium-large size, radially symmetric. Verrucate exosporium, with granulate perine. Axes: 47.5 x $56.2 \mu \mathrm{m}$. Ecological Data: herbaceous 
species present in lowland Atlantic Rain Forest, restinga and secondary vegetation. Commonly found in mangroves. Occurrence: at the Jurubatiba Coastal Woodlands National Park (in Carapebus, NE Rio de Janeiro State), also found in seasonally flooded forests, in swamps, in flodded areas with secondary vegetation with hygrophytes (Santos \& Sylvestre 2001) (Tab. 2). Core Record: E.F. coordinates H39/2, 1000x magnification, GL05/17 (51.63 m depth). References: Roubik \& Moreno (1991).

\section{Adiantum L. Fig. 4E-F}

Description: trilete spores, monads, medium size, radially symmetric, isopolar. Rugulate to verrucate exosporium, perine is absent. Equatorial axis: $47.6-49.4 \mu \mathrm{m}$; polar axis: 37.1-45 $\mu \mathrm{m}$. Comments: one of the most diverse genera found in Brazil (Prado \& Sylvestre 2010). Ecological Data: herbaceous species present in forests, humid and shaded places, or exposed rocks (Winter et al. 2007). Occurrence: Atlantic Rain Forest inselbergs from Rio de Janeiro State (Santos \& Sylvestre, 2006), and southern Espírito Santo State (Aquije \& Santos 2007; Jascone \& Miguel 2007). Also recorded in Mesophilous woodlands at $1500 \mathrm{~m}$ a.s.l., in Sierra Madre Central, México (Gomez-Noguez et al., 2013). Core Record: E.F. coordinates H39/2, 1000x magnification, GL05/17 (51.63 m depth). References: Roubik \& Moreno (1991) and Gomez-Noguez et al. (2013).

\section{Cheilanthes Sw. Fig. $4 \mathrm{G}$}

Description: trilete spores, monads, radially symmetric, isopolar, and subcircular shape. Psilate to scabrate exosporium, perine is absent. Equatorial axis: 50.6-60 $\mu \mathrm{m}$. Ecological Data: herbaceous species from montane forests. Occurrence: in the hills of Atlantic Rain Forest of southern Espírito Santo State (Aquije \& Santos 2007), in the peat bogs of the intermediate valley of Paraíba do Sul River (Garcia 1997), in mesophilous woodland at $1500 \mathrm{~m}$ a.s.l., in the Sierra Madre Central, Mexico (Gomez-Noguez et al. 2013). Also recorded in Holocene sediments from the Argentinean Province, related to the modern highland pteridoflora from Ventania (Argentina), along side with Polypodium e Anemia (Prieto \& Quattrocchio, 1993). Core Record: E.F. coordinates U53/2, 1000x magnification, GL05/08 (13.75 m depth). References: Garcia (1997) and Gomez-Noguez et al. (2013).

\section{Pityrogramma Link. Fig. $4 \mathrm{H}-\mathrm{I}$}

Description: trilete spores, monads, radially symmetric, subtriangular shape. Fossulate exosporium with fossulae concentrated in the center of spores, perine is absent. Longest axis: 56.2-57.2 $\mu \mathrm{m}$; shorter axis: $51.7 \mu \mathrm{m}$. Comments: resembles Pityrogramma calomelanos L. Species from Pteridaceae family are presentely recorded in the Doce River valley (Espirito Santo State), and they make up the group with the largest number of species (Melo \& Salino 2002). Ecological Data: herbaceous plant occupying humid areas within patches of lowland Atlantic Rain Forest, at Jurubatiba
Coastal Woodlands National Park (Santos \& Sylvestre 2001) (Tab. 2). Pityrogramma calomelanosis considered a pioneer species that colonizes disturbed areas (Melo \& Salino 2002). Occurrence: recorded in Atlantic Rain Forest inselbergs from Rio de Janeiro State (Santos \& Sylvestre 2006) and in the low altitude semi-deciduous forests from Doce River Basin, in Minas Gerais State (Melo \& salino 2002). Core Record: E.F. coordinates H53, 1000x magnification, GL05/40 (129.78 m depth). References: Roubik \& Moreno (1991).

\section{Pteris L. Fig. 4J}

Description: trilete spores, monads, radially symmetric, heteropolar, with triangular shape. Exosporium verrucate to regulate in the distal pole while being psilate in the proximal pole. Longest axis: $34.5-39 \mu \mathrm{m}$. Comments: it is one of the most diverse genera recorded in Brazil (Prado \& Sylvestre 2010). Resembles Pteris genus recorded by Macedo et al. (2009). Ecological Data: herbaceous plant with a preference for humid forests on hills, creeks and river margins, and shaded steep hills (Prado 2005). Occurrence: recorded in the high altitude Atlantic Rain Forest of Macaé de Cima, northern Rio de Janeiro State (Prado 2005), Atlantic Rain Forest of Espírito Santo State (Aquije \& Santos 2007), and finally in the semi-deciduous forest of Rio Grande do Sul State (Macedo et al. 2009). Core Record: E.F. coordinates E41, 1000x magnification, GL05/38 (128.1 m depth). References: Macedo et al. (2009).

\section{Family Aspleniaceae}

\section{Asplenium L. Fig. $4 \mathrm{~K}$}

Description: monolete spores, monads, bilaterally symmetric. Psilate exosporium, with echinate, verrucate or reticulate perine. Longest axis: $40 \mu \mathrm{m}$; short axis: $28.8 \mu \mathrm{m}$. Comments: one of the most diverse genera recorded in Brazil (Prado \& Sylvestre 2010). Ecological Data: herbaceous plant that might be rupiculous, commonly found within woodlands, on humid and shaded areas (Lorscheitter et al. 2002 apud Leal \& Lorscheitter 2006). Occurrence: Atlantic Rain Forest on steep hills from Rio de Janeiro (Santos \& Sylvestre 2006) and Espírito Santo states (Aquije \& Santos 2007), and in the swamp forest of Rio Grande do Sul State (Leal \& Lorscheitter 2006). Core Record: E.F. coordinates U53/2, 1000x magnification, GL05/08 (13.75 m depth). References: Roubik \& Moreno (1991).

Family Blechnaceae

20. Blechnum L. Fig. 5A

Description: monolete spores, monads, bilaterally symmetric, ellipsoidal shape, concave-convex. Psilate exosporium with two layers of same thickness. Longest axis: 62.6 $\mu \mathrm{m}$; short axis: $49.3 \mu \mathrm{m}$. Ecological Data: herbaceous to arborescent plant, epiphyte, hemiepyphyte, or rupiculous habit. Invasive species, along with Pteridium aquilinum var. archnoideum in restingas (Santos \& Sylvestre 2001) (Tab. 2). Occurrence: Blechnum serrulatum has been recorded 

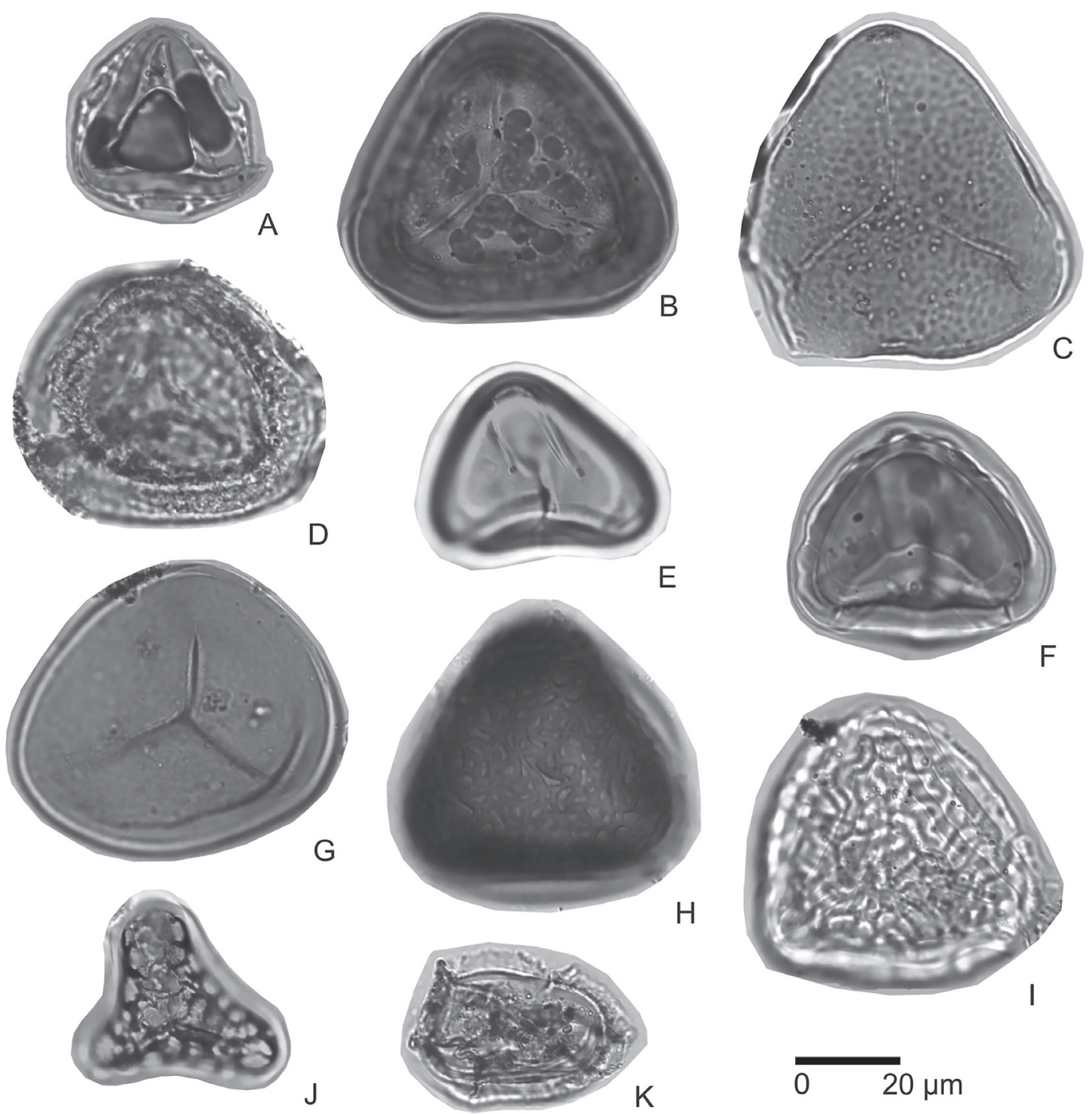

Figure 4. Photomicrographs of cryptogam spores registered in core BU-91-GL-05 (magnification, $\geq 400 x$ and 1000x). Monilophyta: A. Hemitelia; B. Lophosoria; C. Dennstaedtiaceae; D. Acrostichum; E-F. Adiantum; G. Cheilanthes; H-I. Pityrogramma; J. Pteris; K. Asplenium. Scale: 20 um.

on Atlantic Rain Forest inselbergs from Rio de Janeiro (Santos \& Sylvestre 2006) and Espírito Santo states (Aquije \& Santos 2007), in the flooded forest and Ericaceae restinga of Jurubatiba Coastal Woodlands National Park (Norte do Rio de Janeiro), associated to Typha dominguensis and Pityrogramma calomelanos (Santos \& Sylvestre 2001). It is also found on the pteridoflora of Cerrado from Minas Gerais State (Arantes et al. 2008). Core Record: E.F. coordinates M54/3, 1000x magnification, GL05/34 (118.8 m depth). References: Coelho \& Esteves (2008a).

Family Polypodiaceae

21. Microgramma C.Presl. Fig. 5B

Description: trilete spores, monads, medium-large size, bilaterais, triangular shape. Verrucate to reticulate exosporium, perine is presente. Polar diameter: 41-67.6 $\mu \mathrm{m}$; equatorial diameter: 47.3-72.3 $\mu \mathrm{m}$. Comments: it is considered a highly diverse genus recorded in Brazil (Prado \& Sylvestre 2010). Ecological Data: herbaceous or epiphyte species of both lowland and highland Atlantic Rain Forest, and restinga (Santos \& Sylvestre 2001) (Tab. 2). Occurrence: Atlantic Rain Forest inselbergs from Rio de Janeiro (Santos \& Sylvestre 2006) and southern Espírito Santo states (Aquije \& Santos 2007). Also found in Holocene sediments from Argentina province (Prieto \& Quattrocchio 1993). Core Record: E.F. coordinates E41, 1000x magnification, GL05/38 (128.1 m depth). References: Roubik \& Moreno (1991).

\section{Polypodium L. Fig. 5C-D}

Description: monolete spores, monads, medium to large size, heteropolar, and bilaterally symmetric, with concaveconvex shape. Verrucate exosporium. Polar diameter: 29.4- 
$41 \mu \mathrm{m}$; equatorial diameter: $47.3-49.4 \mu \mathrm{m}$. Ecological Data: herbaceous species found in the Amazon forest, riverine forest, lowland Atlantic Rain Forest, restinga, Araucária forest and secondary vegetation (Santos \& Sylvestre 2001) (Tab. 2).Occurrence: Restinga and Atlantic Rain Forest inselbergs from Rio de Janeiro State (Santos \& Sylvestre 2001, 2006), and also in Holocene sediments from Buenos Aires, Argentina (Prieto \& Quattrocchio 1993). Core Record: E.F. coordinates H53, 1000x magnification, GL05/40 (129.78 m depth). References: Roubik \& Moreno (1991).

\section{Vittariaceae}

23. Vittaria Sm. Fig. 5E

Description: trilete spores, monads, medium size. Psilate exosporium with a well-defined laesura, perine is absent. Longest axis: $37.6 \mu \mathrm{m}$; short axis: $35.2 \mu \mathrm{m}$. Ecological Data: epiphyte or rupiculous habit, rarely on the ground of Atlantic Rain Forest, below $1000 \mathrm{~m}$ a.s.l. and riparian forests. It is less frequently recorded in open environments (Tryon \& Tryon 1982 apud Nonato \& Windisch 2004). Comments: Vittaria lineata may produce a larger than average quantity of trilete and monolete spores (Lorscheitter et al. 1998 apud Nonato \& Windisch 2004). Occurrence: It can be found in the south and southeast Brazil (Nonato \& Windisch 2004). It has been recorded in the Reserva Ecológica de Macaé de Cima, in the Itatiaia Plateau, on the Parque da Serra dos Órgãos, and in the Parque da Tijuca (Nonato \& Windisch 2004). It has been recorded also in the Atlantic rain Forest of southern Espírito Santo State (Aquije \& Santos 2007). Core Record: E.F. coordinates M54/3, 1000x magnification, GL05/34 (118.8 m depth). References: Garcia (1994).

Freshwater Microalgi

Kingdom Photosynthetic Protist

Division Chlorophyta

Class Chlorophyceae

Order Chlorococcales

Family Dyctyosphaeriaceae

24. Botryococcus Kützing Fig. 5F

Description: colonies of lobed cells, held together by mucilage, varies in size, irregular shape with psilate surface, yellow to dark-brown color. Dimensions: 38.5-55 $\mu \mathrm{m}$. Comments: resembles Botryococcus braunii Kützing. Ecological Data: widely distributed from tropical to temperate regions. Reproduction takes place in calm or stagnant waters, such as lakes, swamps, bogs, marshes, although it can stand relatively higher salinity of other environments, such as mangroves and estuaries. It can be found in shallow or deep waterbodies (Batten \& Grenfell 1996). Occurrence: Holocene lake sediments of coastal plain from Rio de Janeiro State (Barth et al. 2001; Dias et al. 2001; Luz et al. 2006; 2011; Freitas 2011) and in Quaternary marine sediments from Campos Basin (Behling et al. 2002). Core Record: E.F. coordinates E41, 1000x magnification, GL05/38 (128.1 m depth). References: Freitas et al. (2007).
Class Zygnemaphyceae

Order Zygnematales

Family Zygnemataceae

25. DebaryaWitt. Fig. 5G

Description: zygospores, medium size, spherical shape, formed by two radially symmetric valves, Psilate in the central zone, and slightly granulate and striate in the equatorial zone, hyaline body. Diameter: $42 \mu \mathrm{m}$. Ecological Data: cosmopolitan in oligotrophic lacustrine, shallow and clear freshwater environments. Also present in fertile soils, and lakes and peat bog margins. A few members of Zygnemataceae can withstand more adverse environmental conditions, such as seasonal droughts and higher temperatures during winter (Geel \& Grenfell 1996). Occurrence: in Holocene sediments of coastal plain from Rio de Janeiro State (Barth et al. 2001; Freitas 2011) and southern Brazil (Santa Catarina and Rio Grande do Sul states) (Medeanic 2006; Cancelli et al. 2012). It is also recorded in Quaternary sediments from Colombia (Geel \& Hammen 1978). Core Record: E.F. coordinates H39/2, 1000x magnification, GL05/17 (51.63 m depth). References: Geel \& Hammen (1978).

\section{Zygnema C.A.Agardh Fig. 5H}

Description: zygospores, medium size, spherical to ellipsoidal shape, hyaline body. Psilate with small grooves evenly spread throughout the surface. Longest axis: $35 \mu \mathrm{m}$; short axis: $28 \mu \mathrm{m}$. Ecological Data: cosmopolitan in oligotrophic lacustrine, shallow and clear freshwater environments. Also present in fertile soils, and lakes and peat bog margins. A few members of Zygnemataceae can withstand more adverse environmental conditions, such as seasonal droughts and higher temperatures during winter (Geel \& Grenfell 1996). Occurrence: in Holocene sediments of coastal plain from Rio de Janeiro State (Barth et al. 2001; Freitas 2011) and southern Brazil (Santa Catarina and Rio Grande do Sul states) (Medeanic 2006; Cancelli et al. 2012). It is also recorded in Quaternary sediments from Colombia (Geel \& Hammen 1978). Core Record: E.F. coordinates U53/2, 1000x magnification, GL05/08 (13.75 m depth). References: Geel \& Hammen (1978).

\section{Spirogyra Link Fig. 5I}

Description: zygospores, large size, ellipsoidal shape, reticulate, hyaline body. Largest diameter: $138.5 \mu \mathrm{m}$; smaller diameter: $37 \mu \mathrm{m}$. Ecological Data: freshwater species (Bourrely 1966 apud Cancelli et al. 2012) also present in humid soils (Joly 2002 apud Leal \& Lorscheitter 2006). Occurrence: in Holocene peat sediments from Atlantic Rain Forest (Coelho et al. 2008), coastal plain of northern Rio de Janeiro State (Barth et al. 2001; Luz et al. 2006; 2011), and southern Brazil (Santa Catarina e Rio Grande do Sul states) (Medeanic 2006; Cancelli et al. 2012). Core Record: E.F. coordinates M54/3, 1000x magnification, GL05/34 (118.8 $\mathrm{m}$ depth). References: Freitas et al. (2007). 

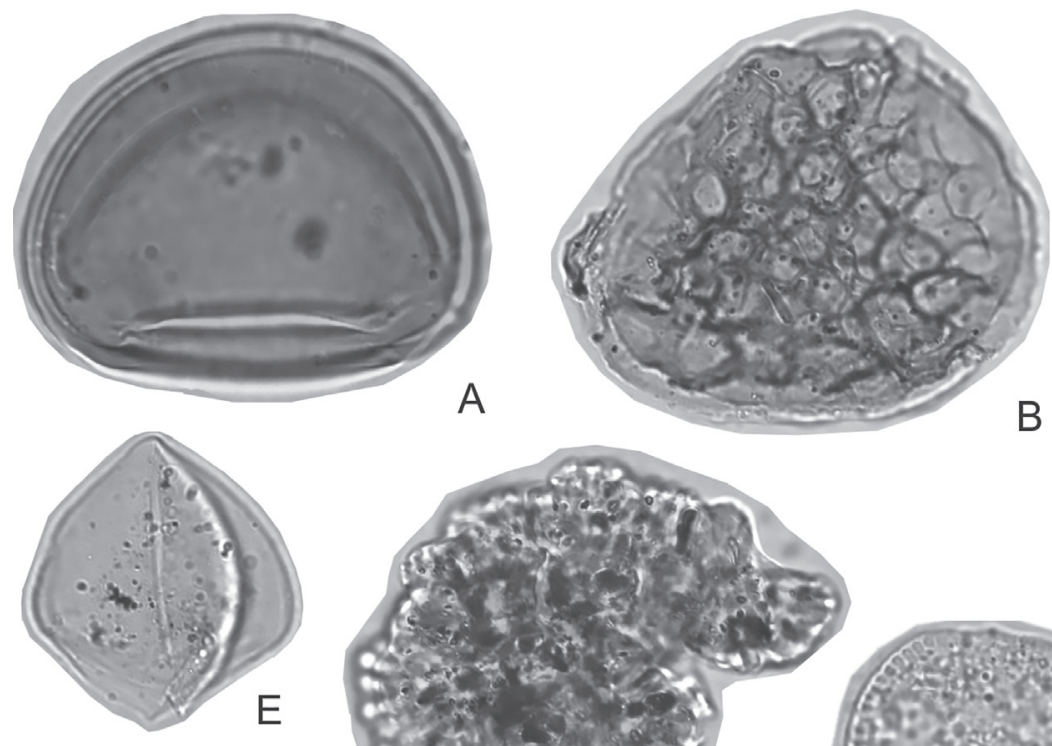

A
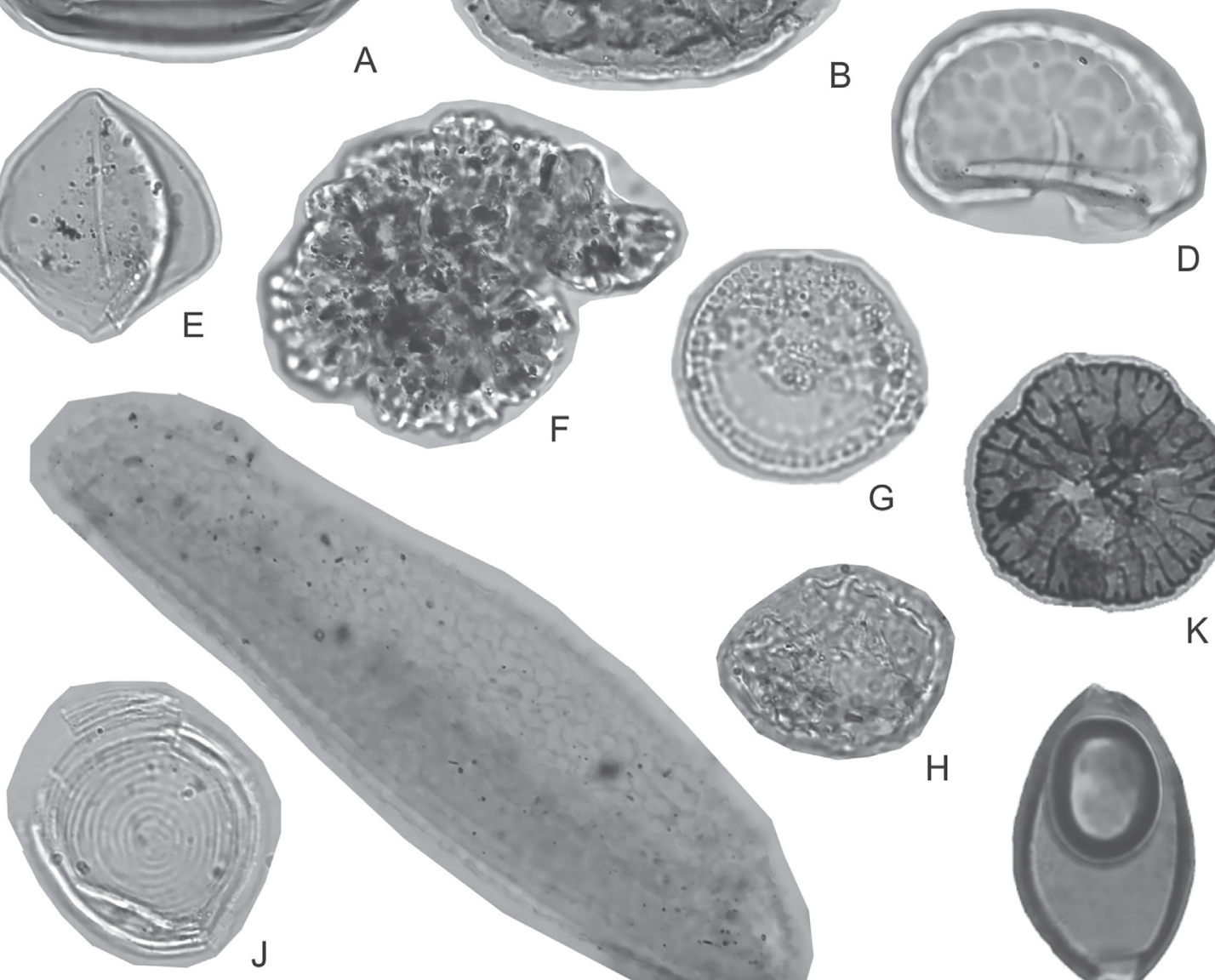

C

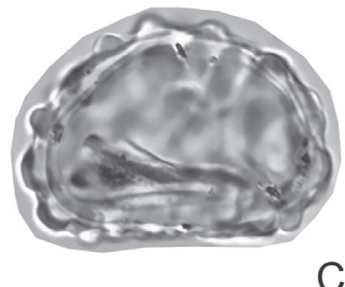

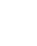
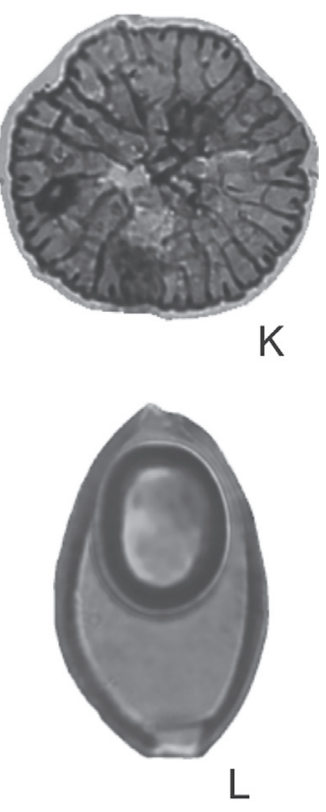

Figure 5. Photomicrographs of cryptogam spores and another palynomorphs registered in core BU-91-GL-05 (magnification, $\geq 400 x$ and $1000 x$ ). Monilophyta: A. Blechnum; B. Microgramma; C-D. Polypodium; E. Vittaria. Freshwater microalgae: F. Botryococcus; G. Debarya; H. Zygnema; I. Spirogyra; J. "Incertae sedis": Pseudoschizaea. Fungal frutification: K. Mycrothyrium. Fungal spore: L. Diporisporites. Scale: $20 \mu \mathrm{m}$.

\section{"Incertae sedis"}

28. Pseudoschizaea Thiergart and Frantz emend. Christopher Fig. 5J

Description: circular to ellipsoidal tests (in polar view), medium size, inaperturate, hyaline body, striate surface with concentric striae. Diameter in frontal view: 37.7- 40 $\mu \mathrm{m}$. Comments: synonym of Concentricites (Rossignol 1962 apud Christopher 1976). Ecological Data: coastal environments with freshwater influence (Medeanic et al. 2008), shallow and stagnant water (Luz et al. 2011). Occurrence: cosmopolitan, in Holocene peat sediments from Atlantic Rain Forest (Coelho et al. 2008), coastal plain of northern Rio de Janeiro State (Barth et al. 2001; Luz et al. 2006; 2011;
Freitas et al. 2007), and southern coast of Santa Catarina State (Cancelli et al. 2012). Also found in the swamp forest of northeastern Rio Grande do Sul State (Scherer \& Lorscheitter 2008). Core Record: E.F. coordinates H41, 1000x magnification, GL05/14 (34.7 m depth). References: Christopher (1976).

\section{Microfungi}

Kingdom Fungi

Phylum Ascomycota

Class Ascomycetes

Order Dothiales

Family Microthyriaceae 


\section{Microthyrium Desm. Fig. 5K}

Description: ascospore with subcircular shape, medium size, with subrectangular and irregular cells, striate surface, dark brown color. A central ostiole is absent. Aproximate diameter: $44 \mu \mathrm{m}$. Comments: the immature forms of $\mathrm{Mi-}$ crothyrium resemble genus Callimothallus Dilcher (1965). Ecological Data: widely distributed in tropical regions, used as indicators for humidity and warm climate (Elsik 1996). Microthyriumhas been recorded as a tree pathogen (e.g. Anacardium and Marantaceae) (Urben \& Matos 1974). Occurrence: Holocene lacustrine sediments of coastal plain from Rio de Janeiro (Freitas \& Carvalho 2011) and Santa Catarina states (Cancelli et al. 2012), and Plio-Pleistocene sediments from Foz do Amazonas Basin (Carvalho 2003). Core Record: E.F. coordinates M54/3, 1000x magnification, GL05/34 (118.8 m depth). References: Kalgutkar \& Jansonius (2000) andFreitas \& Carvalho (2001).

\section{Phylum Eumycota}

Class Fungi Imperfecti

Group Amerosporae Saccardo

30. Diporisporites Hammen Fig. 5L

Description: bilaterally symmetric spores, fusiform shape, medium size, unicelate, diporate, with pores located on the extremities, psilate surface, dark brown color. Longest axis: $48 \mu \mathrm{m}$; short axis: $30 \mu \mathrm{m}$; pore diameter: $5 \mu \mathrm{m}$; wall thickness: $2.6 \mu \mathrm{m}$. Comments: Diporisporites is a name used in artificial systematics, included in the Amerosporae group of Saccardo (1931) apud Kalgutkar \& Jansonius (2000). Ecological Data: a fungus spore characteristic of humid or drenched soils. Frequently recorded in tropical and subtropical regions, in coastal environments, such as lagoons and mangroves, and marine sediments. Are used to suggest humid conditions and a warm climate (Elsik 1996). Occurrence: recorded at Lagoa da Ferradura (Armação dos Búzios County, Rio de Janeiro) associated with aquatic vegetation of brackish soils, such as Typha, Ruppia, Cyperaceae, bryophytes, Botryococcus and marine palynomorphs (Freitas \& Carvalho 2011). In coastal Holocene sediments from Santa Catarina State (Cancelli et al. 2012), and a mangrove from Costa Rica, associated with Botryococcus and Spirogyra (Medeanic et al. 2008). Also recorded in quaternary sediments of Foz do Amazonas Basin (Carvalho 2003). Core Record: E.F. coordinates V46/1, 1000x magnification, GL05/10 (20.07 m depth). References: Kalgutkar \& Jansonius (2000) and Freitas \& Carvalho (2011).

\section{Final remarks}

The taxonomy data and morphological descriptions allowed the identification of 30 different palynomorphs, including bryophyte (sensu lato) and pterydophyte spores, freshwater microalgi, and fungal spores. The ecological informations provided by these palynomorphs help to reveal paleoenvironmental conditions, from the coastal plains, coastal tablelands, and hills near Campos Basin. The spores from plants could be associated to the vegetation types found today in the continent, such as ombrophilous (Atlantic Rainforest), semi-deciduous forest, herbaceous and forest-swampy coastal vegetation. The freshwater microalgi and the microfungi confirm the influence of periodic and permanent flooded environments, swamp forests and aquatic environments. The plant spores found in these sediments from the continental slope suggest the high input of terrigenous during the last glacial stadial, coincident with the low sea level during the Late Pleistocene (Last Glacial Maximum).

\section{Acknowledgments}

We thank Dr. João Graciano Mendonça Filho, from Departamento de Geologia of Universidade Federal do Rio de Janeiro (UFRJ) for making the samples available. Thanks are also due to Taíssa Menezes, from Gerência de Geoquímica - Centro de Pesquisas PETROBRAS, for processing samples, and Dr. Elizabete P. Ferreira, from Gerência de Bioestratigrafia e Paleoecologia Aplicada (BPA), PETROBRAS. We would also like to thank José S. Carrión García and Saul Manzano, from Departamento de Biologia Vegetal (Botanica) of Universidade de Murcia, Spain, for reading this manuscript and discussions about palynotaxonomy. This study received financial support from Universidade PETROBRAS (Petrobras n RH-UC-63.011/2003; Masters Scholarship from AGF. MAC and VGE Recieved CNPq productivity scholarship.

\section{References}

Aquije GM, Santos IKF. 2007. Levantamento florístico de pteridófitas da Reserva Biológica Augusto Ruschi - Santa Teresa - ES. Revista Brasileira de Biociências 5: 909-911.

Arantes AA, Prado J, Ranal MA. 2008. Blechnaceae da Estação Ecológica do Panga, Uberlândia, Minas Gerais, Brasil. Hoenhea 35: 351-357.

Assumpção J, Nascimento MT. 2000. Estrutura e composição florística de quatro formações vegetais de Restinga no complexo lagunar Grussaí/Iquipari, São João da Barra, RJ, Brasil. Acta Botanica Brasilica 14: 301-315.

Barth OM, Luz CP, Toledo MB, Barros M, Silva CG. 2001. Palynological data from Quaternary deposits of two lakes in the northern region of the state of Rio de Janeiro. In: Goodman DK, Clarke RT. (eds.) Proceedings of the IX International Palynological Congress, Houston, Texas, USA. Houston, American Association of Stratigraphic Palynologists Foundation. p. 443-450.

Batten DJ, Grenfell HR. 1996. Botryococcus. In: Jansonius J, McGregor DC (eds.) Palynology: principles and applications. Dallas, American Association of Stratigraphic Palynologists Foundation. Vol. 1. p. 205-214.

Behling H. 2002. South and southeast Brazilian grassland during Late Quaternary times: a synthesis. Palaeogeography, Palaeoclimatology; Palaeoecology 177: 19-27.

Behling H, Arz HW, Pätzold J, Wefer G. 2002. Late Quaternary and Climate dynamics in Southeastern Brazil, inferences from marine slope cores GeoB 3229-2 and GeoB 3202-1. Palaeogeography, Palaeoclimatology, Palaeoecology 179: 227-243.

Caddah LFG, Kowsmann RO, Viana AR. 1998. Slope sedimentary facies associated with Pleistocene and Holocene sea level changes, Campos basin, southeast Brazilian Margin. Sedimentary Geology 115: 159-174. 
Cancelli RR, Souza PA, Neves PCP. 2012. Fungos, criptógamas e outros palinomorfos holocênicos $(7908 \pm 30)$ da Planície Costeira sul-Catarinense, Brasil. Acta Botanica Brasilica 26: 20-37.

Carvalho MA. 2003. Paleoecological and paleoclimatic studies based on palynology of Pliocene and Pleistocene sediments from the Foz do Amazonas Basin, Brazil. NeuesJahrbuch fürGeologie und Paläontologie Abh229: 1-18.

Christopher RA. 1976. Morphology and taxonomic status of Pseudoschizaea Thiergart and Frantz ex R. Potonie Emend. Micropaleontology 22: 143-150.

Coelho CB, Esteves LM. 2008a. Morfologia de esporos de pteridófitas do Parque Estadual das Fontes do Ipiranga (São Paulo, Brasil) Familie: 2-Blechnaceae. Hoehnea 35: 387-393.

Coelho CB, Esteves LM. 2008b. Morfologia de esporos de pteridófitas do Parque Estadual das Fontes do Ipiranga (São Paulo, Brasil) Familys: 6-Dicksoniaceae, 12-Lophosoriaceae, 14-Ophioglossaceae. Hoehnea 35: 419-423.

Coelho LG, Barth OM, Araujo DSD. 2008. Pollen analysis of Holocene sediments from the Poço das Antas National Biological Reserve, Silva Jardim, Rio de Janeiro, Brazil. Anais da Academia Brasileira de Ciências 80: 531-541.

Dias ICA, Menezes M, Sophia MG, et al. 2001. Biodiversidade das algas continentais: listagem taxonômica e considerações fitogeográficas. Parte II, capítulo 3, In: Costa AF, Dias ICA. (eds.) Flora do Parque Nacional da Restinga de Jurubatiba e arredores; Rio de Janeiro, Brasil: listagem, florística e fitogeografia: angiospermas, pteridófitas, algas continentais. Rio de Janeiro, Museu Nacional - Série Livros, 8. p. 171-200.

Dilcher D. 1965. Epiphyllous fungi from Eocene deposits in Western Tenessee, USA. Palaeontographica B 116: 1-54.

Elsik WC. 1996. Fungi. In: Jansonius J, McGregor DC. (eds.) Palynology: principles and applications. Dallas, American Association of Stratigraphic Palynologists Foundation. Vol 1. p. 293-305.

Erdtman G. 1969. Handbook of palynology, morphology-taxonomyecology, an introduction to the study of pollen grains and spores. New York, Hafner Publ. Co.

Ericsson DB, Wöllin G. 1968. Pleistocene climates and chronology in deep-sea sediments. Science 162: 1227-1234.

Ferrazo M, Bauermann SG, Leipnitz II. 2008. Palinomorfos não polínicos provenientes de depósitos quaternários do delta do rio Doce, Espírito Santo, Brasil. Parte 1. Gaea 4: 78-87.

Freitas AG. 2005. Reconstrução paleoclimática com base na análise de palinomorfos continentais em sedimentos pleistocênicos-holocênicos do talude continental brasileiro de Bacia de Campos, RJ. Msc Thesis, Universidade Federal do Rio de Janeiro, Brazil.

Freitas AG. 2011. Registro palinológico e mudanças ambientais holocênicas na península de Armação de Búzios, Região dos Lagos-RJ, Brasil. PhD Thesis, Universidade Federal do Rio de Janeiro, Brazil.

Freitas AG, Carvalho MA. 2011. Esporos e frutificações de fungos holocênicos de testemunho da Lagoa da Ferradura (Armação dos Búzios, Rio de Janeiro, Brasil). Revista Brasileira de Paleontologia 14: 179-188.

Freitas AG, Carvalho MA. 2012. Análise morfológica e inferências ecológicas de grãos de pólen e esporos (últimos $\sim 8.000$ anos) da Lagoa da Ferradura, Armação dos Búzios, RJ, Brasil. Revista Brasileira de Paleontologia 15: 300-318.

Freitas AG, Carvalho MA, Mendonça Filho JG. 2007. Description of bryophyte and pterydophyte spores and fresh-water algae of PleistoceneHolocene sediments of Albacora Slope, Campos Basin, RJ, Brazil. In: Carvalho IS, Cassab RT, Schwanke C, et al. (eds.) Paleontologia: Cenários de Vida. Vol 2. Rio de Janeiro, Interciência. p. 457-470.

Freitas AG, Carvalho MA, Mendonça CBF, Gonçalves-Esteves V. 2013. Pollen grains in quaternary sediments from the Campos Basin, state of Rio de Janeiro, Brazil: Core BU-91-GL-05. Acta Botanica Brasilica 27: 761-772.

Garcia MJ. 1994. Palinologia das turfeiras quaternárias do Médio Vale do Rio Paraíba do Sul, Estado de São Paulo. PhD Thesis, Universidade de São Paulo, Brazil.

Garcia MJ. 1997. Palinologia de turfeiras quaternárias do Médio Vale do Rio Paraíba do Sul, Estado de São Paulo, Brasil, Parte I: Fungos, Algas, Briófitas e Pteridófitas. Revista de Geociências da UnG (n ${ }^{\circ}$ especial): 148-165.
Garcia MJ, Oliveira PE, Siqueira E, Fernandes RS. 2004. A Holocene vegetation and climatic Record from the Atlantic rainforest belt of coastal State of São Paulo, SE Brazil. Review of Palaeobotany and Palynology 131: 181-199.

Geel B, Grenfell HR. 1996. Spores of Zygnemataceae. In: Jansonius J, McGregor DC. (eds.) Palynology: principles and applications. Dallas, American Association of Stratigraphic Palynologists Foundation. Vol 1. p. 173-179.

Geel B, Hammen T. 1978. Zygnemataceae in Quaternary Colombian sediments. Review of Palaeobotany and Palynology 25: 377-391.

Gómez-Noguez F, Pérez-García B, Mendoza-Ruiz A, Orozco-Segovia A. 2013. Flora palinológica de los helechos y licofitas de Río Malila, Hidalgo, México. Botanical Sciences 91: 135-154.

Gregory WA, Hart GF. 1992. Towards a predictive model for the palynological response to sea level changes. Palynos (Society of Sedimentary Geology) 7: 3-33.

IBGE - Instituto Brasileiro de Geografia e Estatística. 1992. Manual técnico da vegetação brasileira. Rio de Janeiro, Fundação Instituto Brasileiro de Geografia e Estatística - IBGE.

Jascone CES, Miguel JR. 2007. Pteridoflora da Estação Ecológica Estadual do Paraíso, Rio de Janeiro, Brasil-resultados preliminares. Saúde \& Ambiente em Revista 2: 37-43.

Judd WS, Campbell CS, Kellog EA, Stevens PF, Donoghue MJ. 2002. Plant systematics: a phylogenetic approach. 2nd. edn. Donoghue, Sinauer Associates, Sunderland, M.A.

Kalgutkar RM, Jansonius J. 2000. Synopsis of fossil fungal spores, mycelia and fructifications. Dallas, American Association of Stratigraphic Palynologists Foundation, Contributions Series, 39.

Leal MG, Lorscheitter ML. 2006. Pólen, esporos e demais palinomorfos de sedimentos holocênicos de uma floresta paludosa, Encosta Inferior do Norderste, Rio Grande do Sul, Brasil. Iheringia 61: 13-47.

Leonhardt A, Lorscheitter ML. 2007. Palinomorfos do perfil sedimentar de uma turfeira em São Francisco de Paula, Planalto Leste do Rio Grande do Sul, Sul do Brasil. Revista Brasileira de Botânica 30: 47-59.

Lorscheitter ML, Romero EJ. 1985. Palynology of Quaternary sediments of the slope core T15, Rio Grande cone, South Atlantic, Brazil. Quaternary of South America and Antarctic Peninsula 3: 55-90.

Luz CFP, Barth OM, Silva CG. 2006. Dinâmica temporal na lagoa do Campelo, região norte do Estado do Rio de Janeiro baseada em estudos palinológicos. Revista Brasileira de Paleontologia 9: 127-136.

Luz CFP, Barth OM, Martin L, Silva CG, Turcq J. 2011. Palynological evidence of the replacement of the hygrophilous Forest by Field vegetation during the last 7,000 years B.P. in the northern coast of Rio de Janeiro, Brazil. Anais da Academia Brasileira de Ciências 83: 939-951.

Macedo RB, Souza PA, Bauermann SG. 2009. Catálogo de polens, esporos e demais palinomorfos em sedimentos holocênicos de Santo Antônio da Patrulha, Rio Grande do Sul, Brasil. Iheringia 64: 43-78.

Martin L, Suguio K, Flexor JM, Dominguez JML, Bittencourt ACSP. 1996. Quaternary sea level history and variation in dynamics along the Central Brazilian coast: consequences on coastal plain construction. Anais da Academia Brasileira de Ciências 68: 303-315.

Medeanic S. 2006. Palynomorphs from surface sediments of intertidal marshes in the estuarine part of the Patos lagoon. Iheringia 61: 49-62.

Medeanic S, Costa César SB, Corrêa ICS. 2006. Os palinomorfos nas reconstruções paleoambientais: Azolla filiculoides Lam. Nos sedimentos holocênicos da planície costeira do Rio Grande do Sul. Gravel 4: 49-61.

Medeanic S, Zamora N, Corrêa ICS. 2008. Non-pollen palynomorphs as environmental indicators in the surface samples from mangrove in Costa Rica. Revista Geológica da América Central 39: 27-51.

Melo LCN, Salino A. 2002. Pteridófitas de duas áreas de floresta da Bacia do Rio Doce no Estado de Minas Gerais, Brasil. Lundiana 3: 129-139.

Mendonça-Filho JG, Carvalho MA, Menezes TR. 2002. Palinofacies. In: Técnicas de procedimentos de trabalho com fósseis e formas modernas comparativas. São Leopoldo, UNISINOS. p. 20-24.

Menéndez GGH. 1962. Estudio de las Anthocerotales y Marchantiales de la Argentina. Tucumán, Universidad Nacional de Tucumán, Instituto Miguel Lillo.

Molisani MM, Salomão MSMB, Ovalle ARC, Rezende CE, Lacerda LD, Carvalho CEV. 1999. Heavy metals in sediments of the lower Paraiba do Sul River and estuary. RJ. Brazil. Bulletin of Environmental Contamination and Toxicology 63: 682-690. 
Montezuma RCM, Araujo DSD. 2007. Estrutura da vegetação de uma restinga arbustiva inundável no Parque Nacional da Restinga de Jurubatiba, Rio de Janeiro. Pesquisas, Botânica 58: 157-176.

Moreno MR, Nascimento MT, Kurtz B. 2003. Estrutura e composição florística do estrato arbóreo em duas zonas altitudinais na mata atlântica de encosta da região do Imbé, RJ. Acta Botanica Brasilica 17: 371-386.

Mudie PJ. 1982. Pollen distribution in Recent marine sediments, eastern Canada. Canadian Journal of Earth Sciences 59: 729-747.

Müller J. 1959. Palynology of Recent Orenoco delta and shelf sediments: reports of Orenoco shelf expeditions. Micropaleontology 5: 1-32.

Neves PCP, Bauermann SG. 2003. Catálogo palinológico de coberturas quaternárias no Estado do Rio Grande do Sul (Guaíba e Capão do Leão), Brasil. Descrições taxonômicas - parte I: fungos, algas, palinomorfos outros e fragmentos de invertebrados. Pesquisas, Botânica 53: 121-149.

Neves PCP, Bauermann SG. 2004. Catálogo palinológico de coberturas quaternárias no Estado do Rio Grande do Sul (Guaíba e Capão do Leão), Brasil. Descrições taxonômicas - parte II: Bryophyta e Pteridophyta. Pesquisas, Botânica 55: 227-251.

Neves PCP, Lorscheitter ML. 1996. Feições de uma mata tropical paludosa em Terra de Areia, Planície Costeira Norte, Rio Grande do Sul, Brasil. Notas técnicas II 9: 28-38.

Nimer E. 1979. Climatologia do Brasil. V. 4. Rio de Janeiro, Secretaria de Planejamento da Presidência da República. IBGE. Série Recursos Naturais e Meio Ambiente.

Nonato FR, Windisch P. 2004. Vittariaceae (Pteridophyta) do Sudeste do Brasil. Revista Brasileira de Botânica 27: 149-161.

Palacios-Rios M. 1994. Lophosoriaceae. In: Rzedowski J, Rzedowski GCA. (eds.) Flora del Bajío y de regiones adyacentes. Vol 25. Pátzcuaro, Instituto de Ecología A.C. Centro Regional del Bajío. p. 1-5.

Pereira AFN, Barros ICL, Xavier SRS, Santiago ACP. 2007. Composição florística e ecologia da pteridoflora de fragmentos de Floresta Atlântica (Reserva Ecológica de Gurjaú, Cabo de Santo Agostinho, Pernambuco, Brasil). Revista Brasileira de Biociências 5: 489-491.

Pereira MCA, Cordeiro SZ, Araujo DSD. 2004. Estrutura do estrato herbáceo na formação aberta de Clusia do Parque Nacional da Restinga de Jurubatiba, RJ, Brasil. Acta Botanica Brasilica 18: 677-687.

Pimentel MCP, Barros MJ, Cirne P, et al. 2007. Spatial variation in the structure and floristic composition of "restinga" vegetation in southeastern Brazil. Revista Brasileira de Botânica 30: 543-551.

Prado J. 2005. Pteridáceas da Reserva Ecológica de Macaé de Cima, Nova Friburgo, Rio de Janeiro, Brasil. Rodriguesia 56: 179-184.

Prado J, Sylvestre LS. 2010. Introdução: as samambaias e licófitas do Brasil. In: Forzza RC. (ed.) Catálogo de plantas e fungos do Brasil [on line]. Rio de Janeiro, Instituto de Pesquisas Jardim Botânico do Rio de Janeiro. Vol 1. p. 69-74.

Prieto AR, Quattrocchio ME. 1993. Briófitas e pteridófitas em sedimentos del Holoceno de la província de Buenos Aires, Argentina. Anales de la Asociación de Palinólogos de Lengua Española 6: 17-37.

Punt W, Blackmore S, Nilsson S, Thomas A. 2007. Glossary of pollen and spore terminology. Review of Palealeobotany and Palynology 143: 1-81.

RADAMBRASIL. 1983. Levantamento de Recursos Naturais. Folhas Rio de Janeiro/Vitória (SF.23 / 24).

Ramos CGV, Sylvestre LS. 2010. Lycopodiaceae no Parque Nacional do Itatiaia, RJ e MG, Brasil. Acta Botanica Brasilica 24: 25-46.

Ramsey C, Buck CE, Burr GS, et al. 2009. IntCal09 and Marine09 radiocarbon age calibration curves, 0 - 50,000 years cal BP. Radiocarbon 51: 1111-1050.

Roubik DW, Moreno JE. 1991. Pollen and spores of Barro Colorado Island. Panamá. Monographs in Sistematic Botany, Missouri Botanical Garden. Vol. 36.

Saccardo PA. 1931. Sylloge fungorum 25: 1-914.
Salgado-Labouriau ML. 1994. História ecológica da Terra. São Paulo, Edgard Blücher.

Santos MG, Sylvestre LS. 2001. Biodiversidade das angiospermas e pteridófitas: pteridófitas. Parte I. In: Costa AF, Dias ICA. (eds.) Flora do Parque Nacional da Restinga de Jurubatiba e arredores; Rio de Janeiro, Brasil: listagem, florística e fitogeografia: angiospermas, pteridófitas, algas continentais. Rio de Janeiro, Museu Nacional - Série Livros, 8. p. 143-152.

Santos MG, Sylvestre LS. 2006. Aspectos florísticos e econômicos das pteridófitas de um afloramento rochoso do Estado do Rio de Janeiro, Brasil. Acta Botanica Brasilica 20: 115-124.

Santos MG, Sylvestre LS, Araujo DSD. 2004. Análise florística das pteridófitas do Parque

Nacional da Restinga de Jurubatiba, Rio de Janeiro, Brasil. Acta Botanica Brasilica 18: 271-280.

Santos AS, Carvalho MA, Santos TM, Freitas AG. 2005. Caracterização da flora de montanha quaternária com base em estudos palinológicos da Bacia da Foz do Amazonas, Brasil. Arquivos do Museu Nacional 63: 425-436.

Scherer \& Lorscheitter ML. 2008. Palinomorfos de fungos e criptógamas em sedimentos quaternários de duas matas com Araucária, Planalto leste do Rio Grande do Sul, Brasil. Acta Botanica Brasilica 22: 131-144.

Schmitt JL, Windisch PG. 2005. Aspectos ecológicos de Alsophila setosa Kaulf. (Cyatheaceae, Pterydophyta) no Rio Grande do Sul, Brasil. Acta Botanica Brasilica 19: 859-865.

Silva GC, Nascimento MT. 2001. Fitossociologia de um remanescente de mata sobre tabuleiros no norte do estado do Rio de Janeiro (Mata do Carvão). Revista Brasileira de Botânica 24: 51-62.

Smith AR, Pryer KM, Schuettpelz E, Korall P, Schneider H, Wolf PG. 2006. A Classification for Extant Ferns. Taxon 55: 705-731.

Stuiver M, Reimer PJ. 1993. Extended ${ }^{14} \mathrm{C}$ data base and revised CALIB 3.0 ${ }^{14} \mathrm{C}$ age calibration program. Radiocarbon 35: 215-230.

Toledo MB, Barth OM, Silva CG, Barros MA. 2009. Testing multivariate analysis in paleoenvironmental reconstructions using pollen records from lagoa Salgada, NE, Rio de Janeiro State, Brazil. Anais da Academia Brasileira de Ciências 81: 757-768.

Traverse A. 1988. Palaeopalinology. Boston, Allen \& Unwin.

Tyson RV. 1995. Sedimentary organic matter. Organic facies and palynofacies. Londres, Chapman \& Hall.

Urben AF, Matos JKA. 1974. Fungos folíícolas em cajueiro Anacardium spp. no Distrito Federal. EMBRAPA Cerrados (CPAC) 6: 20-23.

Viana AR, Faugères JC. 1998. Upper slope sand deposits: the example of Campos Basin, a latest Pleistocene-Holocene record of the interaction between along slope and downslope currents. In: Stoker MS, Evans D, Cramp A. (eds.) Geological Processes on Continental Margins: sedimentation, Mass-Wasting and Stability. London, Geological Society London, Special Publications. Vol. 129. p. 287-316.

Viana AR, Faugères JC, Kowsmann RO, Lima JAM, Caddah LFG, Rizzo JG. 1998. Hydrology, morphology and sedimentology of the Campos continental margin, offshore Brazil. Sedimentary Geology 115: 133-157.

Vicalvi MA. 1997. Zoneamento bioestratigráfico e paleoclimático dos sedimentos do Quaternário superior do talude da Bacia de Campos, RJ, Brasil. Boletim de Geociências da Petrobras 11: 132-165.

Winter SLS, Mynssen, CM, Prado J. 2007. Adiantum (Pteridaceae) no arboreto do Jardim Botânico do Rio de Janeiro, Brasil. Rodriguesia 58: 847-858.

Ybert JP. 1980. Le contenu pollinique de l'atmosphère en Côte d'Ivore et au Tchau. Grana 19: 31-46.

Ybert JP, Carvalho MA, Scheel-Ybert R. 2012. Dicionário temático de morfologia esporopolínica. Rio de Janeiro, Museu Nacional - Série Livros, 47. 